\title{
The Results of Surgico-Pathologic Factors in Patients with Non-Endometrioid Type Endometrial Cancer: Is Tumor Type Important for Lymph Node Metastasis?
}

\author{
Non-Endometrioid Tip Endometrium Kanserinde Cerrahi-Patolojik Faktörlerin Sonuçlari: Lenf Nodu \\ Metastazinda Tümör Tipi Önemli mi?
}

Çigdem Kilic ${ }^{1}$, Osman Turkmen ${ }^{1}$, Gunsu Kimyon Comert ${ }^{1}$, Selcan Sinaci ${ }^{2}$, Bulent Yirci ${ }^{2}$, Yasin Durmus ${ }^{1}$, Alper Karalok ${ }^{1}$, Derman Basaran ${ }^{1}$, Taner Turan ${ }^{1}$

${ }^{1}$ Etlik Zubeyde Hanim Women's Health Teaching and Research Hospital, Gynecologic Oncology Clinic, Ankara, Turkey

${ }^{2}$ Etlik Zubeyde Hanim Women's Health Teaching and Research Hospital, Gynecology Clinic, Ankara, Turkey

\section{ABSTRACT}

Aim: To determine the factors identifying lymph node metastasis and the association between tumor types and surgico-pathologic factors in patients with non-endometrioid type endometrial cancer.

Materials and Methods: This study included 150 patients with nonendometrioid type endometrial cancer whose staging surgeries had already been performed in our clinic.

Results: Tumor types were serous in 65 patients, clear cell in 55, undifferentiated in 23 and mucinous in 8. Sixty-one patients had stage I, 6 patients had stage II, 47 patients had stage III and 36 of them had stage IV disease. Median removed lymph node number was 52 (range; 2-118). Number of the removed lymph node did not change according to tumor type. Lymph node metastasis and non-nodal extra-uterine disease were detected in $47 \%$ and $36 \%$ of patients, respectively. The type of tumor predicted the lymphatic spread, deep myometrial invasion, serosal involvement, adnexal spread, cervical invasion and omental metastasis $(p<0.05)$. The lymphatic spread rate was $65 \%$ for undifferentiated tumor type and $12.5 \%$ for mucinous tumor type. The rate of non-nodal extra-uterine disease was $60.9 \%, 43.8 \%, 21.8 \%$ and none in patients with undifferentiated, serous, clear cell tumor and mucinous type tumor, respectively $(p=0.001)$. In multivariate analysis, it was determined that tumor type (undifferentiated vs. others), cervical invasion and omental metastasis were independent prognostic factors for lymph node metastasis.

Conclusion: Whereas the surgical-pathologic factors were significantly worse in the undifferentiated type than other tumor types, the opposite was true in the mucinous type. Mucinous type tumor is different from other nonendometrioid types in terms of nodal/non-nodal spread. Lymphatic spread was observed in slightly more than $10 \%$ of patients with mucinous tumor and non-nodal extra-uterine disease did not exist in those.

Key Words: Endometrial Cancer, Serous type, Mucinous type, Undifferentiated type, Clear Cell type, Lymph node metastasis

\section{ÖZET}

Amaç: Non-endometrioid tip endometrium kanserli hastalarda lenf nodu metastazını belirleyen faktörlerin ve tümör tipi ile cerrahi ve patolojik faktörlerin arasındaki ilişkinin araştırılması.

Yöntemler: Bu çalışmada, evreleme cerrahisi kliniğimizde yapılmış 150 nonendometrioid tip endometrium kanserli hasta değerlendirilmiştir.

Bulgular: Tümör tipi 65 hastada seröz, 55 hastada berrak hücreli, 23 hastada andifferansiye ve 8 hastada müsinöz tipti. Altmış bir hasta evre I, altı hasta evre II, 47 hasta evre III ve 36 hasta evre IV hastalığa sahipti. Çıkarılan lenf nodu sayısının ortanca değeri 52'ydi (aralık 2-118). Çıkarılan lenf nodu sayısının tümör tipine göre değişmediği tespit edildi. Lenf nodu metastazı ve non-nodal ekstrauterin hastalık sırasıyla \%47 ve \%36 hastada mevcuttu. Tümör tipinin; lenf nodu metastazını, derin myometrial invazyonu, serozal tutulumu, adneksal metastazı, servikal invazyonu ve omental metastazı öngörmede etkili olduğu bulundu $(p<0.05)$. Andifferansiye tipte lenfatik yayılım oranının $65 \%$ ve müsinöz tipte lenfatik yayılım oranının $\% 12.5$ olduğu belirlendi. Andifferansiye tip, seröz tip, berrak hücreli tip ve müsinöz tip tümörlerde non-nodal ekstrauterin yayılım oranının sırasıyla \%60.9, \%43.8, $\% 21.8$ ve $\% 0$ olduğu tespit edildi $(p=0.001)$. Yapılan multivaryant analizde; tümör tipi (andifferansiye vs. diğerleri), servikal invazyon ve omental metastaz lenf nodu metastazı için bağımsız prognostic faktörler olarak belirlendi.

Sonuç: Andifferansiye tip tümörlerde cerrahi ve patolojik faktörler diğer tümör tiplerine oranla belirgin ölçüde daha kötü olmakla birlikte müsinöz tip tümörlerde bu durum tam tersiydi. Müsinöz tip tümörler nodal ve non-nodal yayılım açısından diğer non-endometrioid tümör tiplerinden farklı bulundu. Lenfatik yayılım müsinöz tip tümörlerin yaklaşık \%10'unda tespit edilirken; non-nodal ekstrauterin yayılım bu hastalarda izlenemedi.

Anahtar Sözcükler: Endometrium kanseri, seröz tip, müsinöz tip andifferansiye tip, berrak hücreli tip, lenf nodu metastazı

Kabul Tarihi: 09.07.2017 


\section{INTRODUCTION}

With 300.000 new diagnosis every year, endometrium cancer (EC) is the most frequent cancer of female genital tract and the fourth cancer among all cancer types (1). EC is mostly diagnosed at early stage and the main treatment is surgery. However, extra-uterine spread could be determined in $20 \%$ of the cases (2). Five-year overall survival is over $80 \%$ for low grade tumors in early stage of EC (3).

EC has been staged surgically according to the International Federation Obstetricians and Gynecologists (FIGO) since 1988 (4). According to this staging system, the disease had been staged as IIIC according to presence of the metastatic lymph nodes without occurrence of abdominal or extraabdominal spread. However, in 2009, FIGO revised the staging system and stage IIIC was split into two groups according to occurrence of paraaortic lymph node metastasis (5). Occurrence of pelvic lymph node metastasis only has been accepted as stage IIIC1 and existence of paraaortic lymph node metastasis has been staged as IIIC2.

Bookman defined the dual model in endometrial carcinogenesis for the first time in 1983 according to histo-pathologic, clinic, epidemiologic and genetic characteristics (6). According to this definition, endometrioid type tumor which is accepted as Type I EC is determined in $80 \%$ of the patients and is estrogen dependent. On the other hand, Type II EC, which is estrogen independent, is used to define the some non-endometrioid type tumors. Non-endometrioid tumors include serous, clear cell, undifferentiated and mucinous types. It is known that Type II EC; specifically serous, clear cell and undifferentiated types, is more aggressive than endometrioid type tumor with respect to clinic and surgico-pathologic factors. Serous type is the most common tumor in this group. Serous type tumor is the cause in $10 \%$, clear cell type is in $3 \%(7)$, undifferentiated type is in 1-9\% (8-11) and mucinous type is in $1-5 \%$ (12) of the EC. In spite of that, serous and clear type tumors are responsible from nearly half of the mortality in endometrium cancer ( 7 , 13). Although the evidence is not sufficient because of the lack of data, it has been accepted that whereas undifferentiated tumor is accepted as an aggressive type tumor, mucinous tumor type can have almost similar aggressiveness level with endometrioid type. 5-year overall survival has been reported as $65-71 \%$ for serous tumor, $77-85 \%$ for clear cell and $40-70 \%$ for undifferentiated tumor type (14-18).

The objective of this study is to evaluate factors identifying lymph node metastasis and the association between tumor type and surgico-pathologic factors in patients with non-endometrioid type EC.

\section{MATERIALS and METHODS}

This study included 150 patients whose staging surgeries had been performed in our oncology clinic between January 1993 and October 2016 and who had non-endometrioid tip ( 65 patients with serous type, 55 patients with clear cell type, 8 patients with mucinous type and 23 patients with undifferentiated type) type EC according to final pathology results. Data of the patients were obtained from electronic database and patients' files, retrospectively. Patients whose surgeries had not been performed in our clinic, with endometrioid type or mixed type adenocancer, whose tumors had sarcoma component, with secondary primary tumor, who didn't have lymphadenectomy performed and the ones having neo-adjuvant treatment were excluded. The institutional review board approval was obtained. Staging were performed according to FIGO 2009 criteria. During the statistical analysis, cervical stromal and glandular spread was both defined as cervical invasion in order to evaluate the effect on lymphatic spread. Tumor size was measured as the longest tumor diameter.
Adnexal spread, uterine serosal involvement, peritoneal involvement, positive peritoneal cytology and solid organ metastasis were all defined as extrauterine non-nodal disease.

Lymphovascular space invasion (LVSI) was defined as the tumoral cells or cell clusters holding on vessels' wall that were stained with hematoxylin and eosin (H\&E) in the pathologic sections containing both tumor and the surrounding healthy tissue. Omentum was pathologically examined through 2-3 sections taken from macroscopic tumor and suspicious areas, or through 3-5 sections taken from healthy looking omentum tissue. Pathologic examination of the hysterectomy material was performed with at least 4 cutout sections. Lymph node examination was performed as follows: the material was taken into paraffin block (i) directly, if the size was less than 1 $\mathrm{cm}$; (ii) with cutting into horizontally at least two pieces changing according to size, if it was more than $1 \mathrm{~cm}$. In the presence of the macroscopic tumor, only that part was directly taken into paraffin block. The sections has been evaluated through hematoxylin and eosin stain.

Frozen-section is utilized routinely for the patients with EC in our clinic and staging surgery is performed for the patients whose preoperative pathologic diagnosis or frozen-section revealed non-endometrioid adenocarcinoma. The standard staging surgery included cytological sampling, total abdominal hysterectomy, bilateral salpingo-oophorectomy, systematic pelvic and paraaortic lymphadenectomy and omentectomy. During the intra-operative observation, cytoreductive surgery techniques have been applied in addition to staging surgery in the presence of macroscopic tumor.

Lymphadenectomy was performed in most of the patients by skeletonizing pelvic and paraaortic regions. Nevertheless, there were patients treated by sampling of the suspicious lymph nodes at the discretion of the surgeon. Since patients with positive lymph nodes were evaluated, patients who had lymph node sampling were also included in the study. Bilateral pelvic lymphadenectomy was performed to complete skeletonization, with all lymphatic tissue of the common, external and internal iliac vessels and the obturator fossa that was removed after visualization of the obturator nerve. The superior surgical dissection margin for the pelvic nodes was the aortic bifurcation, and the anterior distal surgical dissection margin was the circumflex iliac vein. The presacral lymphatic tissue was harvested separately. The upper limit of paraaortic lymphadenectomy was renal veins.

Factors identifying the lymph node metastasis were compared by applying chi-square test for categorical parameters and by using Anova Table Test for continuous parameters in univariate analysis. Factors that were statistically significant in the univariate analysis were analyzed with Logistic Regression Analysis in multi-variant analysis. The statistical analysis was performed by using SPSS 17.0 (Statistical Package for Social Sciences, SPSS Inc., Chicago IL, USA) and p-value $<0.05$ was accepted as a statistically significance.

\section{RESULTS}

The mean age of the entire cohort was 61.4 years ranged between 32 and 77. The mean tumor size was $38 \mathrm{~mm}$ (range; 1-155). The tumor type was serous in 65 patients, clear cell in 55, undifferentiated in 23 and mucinous in 8. According to FIGO 2009, 61 patients had stage I, 6 patients had stage II, 47 patients had stage III and 36 of them had stage IV disease. Whereas 26 (17.3\%) patients did not have myometrial invasion, myometrial invasion was equal or above the half $(\geq 1 / 2)$ in $68(45.4 \%)$ patients. Uterine serosal involvement was determined in $19(12.7 \%)$ of these patients. Cervical involvement was identified in 48 (32\%) patients and among them, cervical spread was observed as a stromal invasion in 35 cases. There were LVSI in 65 (42.7\%) patients and malignity positive peritoneal cytology in 30 (20\%) patients. The tumor spread to adnexa in $39(26 \%)$ patients. Thirty-three (23.9\%) of the 138 patients who underwent omentectomy had omental metastasis. Non-nodal extra-uterine disease was detected in 54 (36\%) patients. The distribution of surgical and pathological factors detailed in Table 1. 
Table 1. Clinical, pathological and surgical characteristics of all cohort

\begin{tabular}{|c|c|c|c|}
\hline Characteristics & & Mean / n & Median (range) / \% \\
\hline Age at initial diagnosis (year) & & 61.4 & $62(32-77)$ \\
\hline \multirow[t]{4}{*}{ Tumor size $(\mathrm{mm})$} & & 38 & $35(1-150)$ \\
\hline & IA & 49 & 32.7 \\
\hline & IB & 12 & 8 \\
\hline & II & 6 & 4 \\
\hline \multirow[t]{6}{*}{ FIGO 2009 stage } & IIIA & 7 & 4.7 \\
\hline & IIIC1 & 17 & 11.3 \\
\hline & IIIC2 & 23 & 15.3 \\
\hline & IVB & 36 & 24 \\
\hline & Serous & 65 & 42.7 \\
\hline & Clear cell & 55 & 36.7 \\
\hline \multirow{3}{*}{ Tumor type } & Mucinous & 8 & 5.3 \\
\hline & Undifferentiated & 23 & 15.3 \\
\hline & No invasion & 26 & 17.3 \\
\hline \multirow{4}{*}{ Depth of myometrial invasion } & $<1 / 2$ & 56 & 37.3 \\
\hline & $\geq 1 / 2^{1}$ & 49 & 32.7 \\
\hline & Serosal invasion & 19 & 12.7 \\
\hline & Negative & 102 & 68 \\
\hline \multirow[t]{3}{*}{ Cervical invasion } & Glandular & 13 & 8.7 \\
\hline & Stromal & 35 & 23.3 \\
\hline & Negative & 55 & 36.7 \\
\hline \multirow[t]{3}{*}{ Lymphovascular space invasion } & Positive & 64 & 42.7 \\
\hline & Not reported & 31 & 20.7 \\
\hline & Negative & 107 & 71.3 \\
\hline \multirow[t]{3}{*}{ Peritoneal cytology } & Positive & 30 & 20 \\
\hline & Not reported & 13 & 8.7 \\
\hline & Negative & 110 & 73.3 \\
\hline \multirow[t]{3}{*}{ Adnexal metastasis } & Positive & 39 & 26 \\
\hline & Not reported & 1 & 0.7 \\
\hline & Negative & 105 & 70 \\
\hline \multirow[t]{2}{*}{ Omental metastasis } & Positive & 33 & 22 \\
\hline & Omentectomy not performed & 12 & 8 \\
\hline \multirow{2}{*}{ Non-nodal extrauterine disease } & Negative & 96 & 64 \\
\hline & Positive & 54 & 36 \\
\hline Number of harvested lymph node & & 50.5 & $52(2-118)$ \\
\hline \multirow[t]{3}{*}{ Number of metastatic lymph node } & & 10.5 & $5(1-55)$ \\
\hline & Negative & 80 & 53.3 \\
\hline & Isolated pelvic & 29 & 19.3 \\
\hline \multirow[t]{3}{*}{ Lymph node metastasis } & Isolated paraaortic & 9 & 6 \\
\hline & Pelvic \& paraaortic & 31 & 20.7 \\
\hline & Metastatic region unknown & 1 & 0.7 \\
\hline
\end{tabular}

${ }^{1}$ : Except for uterine serosal invasion

Median removed lymph node number was 52 (range; 2-118). This number was 15 (range; 2-55) for the paraaortic region and 37 (range; 1-69) for the pelvic region. The removed lymph node number was 25 or more in $84 \%$ of the patients. The lymph node metastasis was identified in $80(46.7 \%)$ patients. Lymphatic spread was observed at only paraaortic region in $9(6 \%)$ patients, at only pelvic area in 29 (19.3\%) patients and at both paraaortic and pelvic areas in $31(20.7 \%)$ patients. Data about the metastatic lymph node count was not available for 1 patient. Median metastatic lymph node number was 5 ranging from 1 to 55 . The number of removed lymph nodes did not change with the type of tumor. Median of the total number of removed lymph nodes was 53 (range; 13-80) for undifferentiated type, 54 (range; 14-118) for serous type, 47 (range; 2-102) for clear cell type and 34 (range; $10-69)$ for mucinous type $(p=0.082)$. The number of removed lymph nodes did not differ according to the stage $(p=0.871)$. The median removed lymph node number were 52 (range; $2-99$ ) in 36 patients with stage IV and lymph node metastasis was identified in $30(83.3 \%)$ of these patients.
The association between surgical-pathologic factors and lymphatic spread was evident. As an outcome of univariate analysis; tumor type, depth of myometrial invasion, cervical spread, LVSI, tumor positivity in peritoneal cytology, adnexal metastasis, omental involvement and presence of nonnodal extra-uterine disease were significant for tumor spread to lymph nodes (Table 2). Age and tumor size did not determine the lymphatic spread. In the case of undifferentiated tumor type, lymphatic metastasis was detected in $65.2 \%$ of patients (paraaortic lymph node metastasis in $43.5 \%$ and pelvic lymph node metastasis in $60.9 \%$ ), whereas this rate was $51.6 \%$ (paraaortic lymph node metastasis in $32.8 \%$, pelvic lymph node metastasis in 43.8\%) in serous tumor type and $38.2 \%$ for clear cell type (paraaortic lymph node metastasis in $18.5 \%$, pelvic lymph node metastasis in $30.9 \%$ ). Lymph node metastasis was detected in $12.5 \%$ of cases with mucinous tumor type, and none of them had paraaortic spread. 
Table 2. Factors predicting lymph node metastasis

\begin{tabular}{|c|c|c|c|c|c|c|}
\hline \multirow[t]{2}{*}{ Factors } & \multicolumn{6}{|c|}{ Positive lymph node (\%) } \\
\hline & Pelvic & $P$ value & Paraaortic & P value & Total & $P$ value \\
\hline \multicolumn{7}{|l|}{ Age } \\
\hline$\leq 65$ years & 39.4 & \multirow{2}{*}{0.833} & 23 & \multirow{2}{*}{0.107} & 44.4 & \multirow{2}{*}{0.447} \\
\hline$>65$ years & 41.2 & & 365 & & 51 & \\
\hline \multicolumn{7}{|l|}{ Tumor type } \\
\hline Serous & 43.8 & \multirow{4}{*}{0.030} & 32.8 & \multirow{4}{*}{0.034} & 51.6 & \multirow{4}{*}{0.027} \\
\hline Clear Cell & 30.9 & & 18.5 & & 38.2 & \\
\hline Mucinous & 12.5 & & 0 & & 12.5 & \\
\hline Undifferentiated & 60.9 & & 43.5 & & 65.2 & \\
\hline \multicolumn{7}{|l|}{ Depth of myometrial invasion } \\
\hline No invasion & 15.4 & \multirow{3}{*}{0.001} & 24 & \multirow{3}{*}{0.394} & 23.1 & \multirow{3}{*}{0.002} \\
\hline Invasion $<1 / 2$ & 30.4 & & 17.9 & & 35.7 & \\
\hline Invasion $\geq 1 / 21$ & 55.1 & & 29.2 & & 61.2 & \\
\hline \multicolumn{7}{|l|}{ Serosal invasion } \\
\hline Negative & 36.6 & \multirow{2}{*}{0.027} & 23.3 & \multirow{2}{*}{0.002} & 42.7 & \multirow{2}{*}{0.012} \\
\hline Positive & 63.2 & & 57.9 & & 73.7 & \\
\hline \multicolumn{7}{|l|}{ Lymphovascular space invasion } \\
\hline Negative & 25.5 & \multirow{2}{*}{0.004} & 9.3 & \multirow{2}{*}{$<0.0001$} & 29.1 & \multirow{2}{*}{0.001} \\
\hline Positive & 51.6 & & 42.2 & & 59.4 & \\
\hline \multicolumn{7}{|l|}{ Cervical invasion } \\
\hline Negative & 39.4 & \multirow{3}{*}{$<0.0001$} & 15 & \multirow{3}{*}{$<0.0001$} & 35.7 & \multirow{3}{*}{$<0.0001$} \\
\hline Glandular & 46.2 & & 30.8 & & 53.8 & \\
\hline Stromal & 68.6 & & 62.9 & & 77.1 & \\
\hline Peritoneal cytology & & & & & & \\
\hline Negative & 29.9 & $<001$ & 19 & > & 34.6 & $<00001$ \\
\hline Positive & 73.3 & $<0.0001$ & 60 & $<0.0001$ & 86.7 & $<0.0001$ \\
\hline Adnexal involvement & & & & & & \\
\hline Negative & 60 & & 17.6 & & 34.5 & $<0,0001$ \\
\hline Positive & 71.5 & $<0.0001$ & 56 & $<0.0001$ & 82 & $<0.0001$ \\
\hline Omental metastasis & & & & & & \\
\hline Negative & 31.4 & & 21.2 & & 36.2 & \\
\hline Positive & 66.7 & $<0.0001$ & 51.5 & 0.001 & 81.8 & $<0.0001$ \\
\hline Non-nodal extrauterine disease & & & & & & \\
\hline Negative & 24 & > & 12.8 & 1 & 28.1 & > \\
\hline Positive & 68.5 & $<0.0001$ & 53.7 & $<0.0001$ & 79.6 & $<0.0001$ \\
\hline Tumor size (mm) & & & & & & \\
\hline$\leq 35 \mathrm{~mm}$ & 33.3 & & 25.5 & & 43.1 & \\
\hline$>35 \mathrm{~mm}$ & 50 & 0.100 & 38.6 & 0.169 & 56.8 & 0.184 \\
\hline
\end{tabular}

There were a significant correlation between tumor type and clinical or surgical-pathologic factors. Whereas patients with serous tumor type were older, tumor size was significantly larger in undifferentiated type $(p=0.011$ and $p=0.001$, respectively) (Table 3 ). Surgical-pathologic factors were worse in the undifferentiated type than the others.
Deep myometrial invasion and LVSI were more in this tumor type; besides, the possibility of the disease spread out of the uterine corpus (cervical invasion and non-nodal extra-uterine spread) was evident (Table 3). Nonnodal extra-uterine disease was present in $60.9 \%$ of patients with undifferentiated type. This rate was $43.8 \%$ for serous tumor type and $21.8 \%$ for clear cell tumor type $(p=0.001)$. Non-nodal extra-uterine spread was not present in the mucinous tumor type. 
Table 3. The relationship with tumor type and other factors

\begin{tabular}{|c|c|c|c|c|}
\hline \multirow[t]{2}{*}{ Factors } & \multicolumn{4}{|l|}{ Tumor type } \\
\hline & Serous & Clear Cell & Mucinous & Undifferentiated \\
\hline & \multicolumn{4}{|c|}{ Mean (median; range) } \\
\hline Age (year) & $63.5(64 ; 46-76)$ & $61.4(62 ; 32-77)$ & $56.8(56 ; 50-71)$ & $57.4(59 ; 35-75)$ \\
\hline$P$ value & 0.011 & & & \\
\hline Tumor size $(\mathrm{mm})$ & $29(26 ; 1-60)$ & $42(33 ; 15-150)$ & $39(28 ; 10-90)$ & $58(50 ; 25-100)$ \\
\hline \multirow[t]{2}{*}{$P$ value } & 0.001 & & & \\
\hline & Patient number & & & \\
\hline \multicolumn{5}{|l|}{ Depth of myometrial invasion } \\
\hline No invasion & $14(25.5)$ & $12(23.1)$ & 0 & 0 \\
\hline Invasion $<1 / 2$ & $18(32.7)$ & 27 (51.9) & $4(50)$ & $7(43.8)$ \\
\hline Invasion $\geq \frac{1}{2}{ }^{1}$ & $23(41.8)$ & $13(25)$ & $4(50)$ & $9(56.2)$ \\
\hline$P$ value & 0.050 & & & \\
\hline \multicolumn{5}{|l|}{ Serosal invasion } \\
\hline Negative & 55 (85.9) & $52(94.5)$ & $8(100)$ & $16(69.6)$ \\
\hline Positive & $9(14.1)$ & $3(5.5)$ & 0 & $7(30.4)$ \\
\hline$P$ value & 0.015 & & & \\
\hline \multicolumn{5}{|l|}{ Lymphovascular space invasion } \\
\hline Negative & $23(42.6)$ & $26(63.4)$ & $5(100)$ & $1(5.3)$ \\
\hline Positive & $31(57.4)$ & $15(36.6)$ & 0 & $18(94.7)$ \\
\hline$P$ value & $<0.0001$ & & & \\
\hline \multicolumn{5}{|l|}{ Cervical invasion } \\
\hline Negative & $40(62.5)$ & $41(74.5)$ & $8(100)$ & $13(56.5)$ \\
\hline Glandular & $4(6.3)$ & $8(14.5)$ & 0 & $1(4.3)$ \\
\hline Stromal & $20(31.2)$ & $6(10.9)$ & 0 & $9(39.1)$ \\
\hline$P$ value & 0.015 & & & \\
\hline \multicolumn{5}{|l|}{ Peritoneal cytology } \\
\hline Negative & $44(74.6)$ & $42(84)$ & $8(100)$ & $13(65)$ \\
\hline Positive & $15(25.4)$ & $8(16)$ & 0 & $7(35)$ \\
\hline$P$ value & 0.127 & & & \\
\hline \multicolumn{5}{|l|}{ Adnexal involvement } \\
\hline Negative & $43(67.2)$ & $46(85.2)$ & $8(100)$ & $13(56.5)$ \\
\hline Positive & $21(32.8)$ & $8(14.8)$ & 0 & $10(43.5)$ \\
\hline$P$ value & 0.009 & & & \\
\hline \multicolumn{5}{|l|}{ Omental metastasis } \\
\hline Negative & $42(68.9)$ & $40(81.6)$ & $7(100)$ & $16(76.2)$ \\
\hline Positive & 19 (31.1) & $9(18.4)$ & 0 & $5(23.8)$ \\
\hline$P$ value & 0.188 & & & \\
\hline \multicolumn{5}{|l|}{ Non-nodal extrauterine disease } \\
\hline Negative & $26(56.2)$ & $43(78.2)$ & $8(100)$ & $9(39.1)$ \\
\hline Positive & $28(43.8)$ & $12(21.8)$ & 0 & $14(60.9)$ \\
\hline$P$ value & 0.001 & & & \\
\hline
\end{tabular}

Logistic regression analysis was performed to determine the correlation among predicative factors that were found to be significant for lymph node metastasis in univariate analysis.

Table 4. Factors predicting lymph node metastasis, multivariate analysis

\begin{tabular}{|c|c|c|c|}
\hline Factors & OR & \%95 Confidence Interval & p value \\
\hline Tumor type (undifferentiated vs. other) & 3.489 & $1.413-10.650$ & 0.028 \\
\hline Cervical invasion (positive vs. negative) & 3.606 & $1.551-8.386$ & 0.003 \\
\hline Omental metastasis (positive vs. negative) & 8.074 & $2.917-22.346$ & $<0.001$ \\
\hline
\end{tabular}

\section{DISCUSSION}

The relationship between surgical-pathologic factors; especially lymph node metastasis, and tumor type is evident in $\operatorname{EC}(3,4,9)$. Compared to endometrioid type, local and systemic spread of tumor is significantly higher in non-endometrioid type. Age, tumor type, grade, depth of myometrial invasion, LVSI, cervical spread, pelvic and/or paraaortic lymph node metastasis and extra-uterine non-nodal spread determine the survival of the disease $(7,13-20)$.

There is a close association between lymph node metastasis and surgicalpathologic risk factors that predict poor prognosis in EC. Lymphatic spread is an important predictor of survival in EC. Tumor type is associated with lymphatic spread, other surgical-pathological factors such as cervical spread, LVSI, myometrial invasion depth, tumor positivity in peritoneal cytology,
Based on this, multi-variant analysis was performed by modeling including tumor type (undifferentiated vs. others), cervical invasion (positive vs. negative), and omental metastasis (positive vs. negative). Three parameters used in the model were independent prognostic factors in terms of lymph node metastasis (Table 4). 
In this study which the association between non-endometrioid tumor type and disease spread was investigated, lymphatic spread and non-nodal extrauterine disease were detected in $47 \%$ and $36 \%$ of patients, respectively. The type of tumor predicted the lymphatic spread, deep myometrial invasion, serosal involvement, adnexal spread, cervical invasion and omental metastasis. Tumor type (undifferentiated vs. others), cervical invasion and omental metastasis were independent prognostic factors for lymphatic spread. Pelvic and/or para-aortic lymphatic spread was $12.5 \%$ in mucinous type, $38.2 \%$ in clear cell type, $51.6 \%$ in serous type and $65.2 \%$ in undifferentiated type. The likelihood of lymphatic spread in the undifferentiated type was increased about 3.5-fold (OR: 3.489 , Cl: $1.413-$ $10.650 ; p=0.028$ ). Whereas the surgical-pathologic factors were significantly worse in the undifferentiated type than other tumor types, the opposite was true in the mucinous type.

In a multicenter study involving 112 cases with mucinous adenocarcinoma of the endometrium, mucinous histological type alone was found to be an independent risk factor for lymph node involvement (OR: 2.2, Cl: 1.1-4.5; $p=0.02$ ) (19). Additionally, it was shown that the presence of more than half $(\geq 1 / 2)$ myometrial invasion, positivity of LVSI and tumor grade were associated with lymph node involvement (19).

Nomura et al. reported that paraaortic lymph node metastasis in EC was related with tumor grade, myometrial invasion, pelvic lymph node metastasis, vascular space invasion, parametrial invasion, cervical involvement and adnexal metastasis (22). Kumar et al. found that tumor histology, myometrial invasion, grade and extra-uterine metastatic disease were related with lymph node metastasis in EC (23). Pelvic and paraaortic lymph node metastases were highly associated with deep myometrial invasion, high grade and presence of the macroscopic extra-uterine disease (23). These findings of Kumar et al. are consistent with our study.

The main limitation of this study is its retrospective nature. In addition, tumor types other than serous and clear cell type are limited. On the other hand, the strengths of this study are originating from a single medical center, complete lymphadenectomy performed in most of the patients, high number of removed lymph nodes and evaluated of the specimens by experienced gyneco-pathologists.

In conclusion, mucinous type differs from other non-endometrioid types in terms of nodal/non-nodal spread of the disease in EC. In general, there were lymph node metastasis in $47 \%$ of patients with non-endometrioid type EC and paraaortic lymph nodes in $40 \%$ of them. However, the lymphatic spread rate was $65 \%$ for undifferentiated tumor type and $12.5 \%$ for mucinous tumor type. Whereas non-nodal extra-uterine disease was detected in more than half of the patients with serous type and undifferentiated type and in one third of clear cell type, none of the the patients with mucinous type had it. Although the number of patients with mucinous type EC is not sufficient to produce a clear conclusion in the present study, the mucinous type appears to behave differently among the non-endometrioid types. Multicenter studies are needed to clarify the pathological spread and clinical behavior of the mucinous type.

\section{Conflict of interest}

No conflict of interest was declared by the authors.

\section{REFERENCES}

1. Jemal A, Bray F, Center MM, Ferlay J, Ward E, Forman D. Global cancer statistics. CA Cancer J Clin. 2011; 61:69-90.

2. Creasman WT, Morrow CP, Bundy BN, Homesley HD, Graham JE, Heller PB. Surgical pathologic spread patterns of endometrial cancer. A Gynecologic Oncology Group Study. Cancer 1987; 60(8 Suppl):2035-41
3. Lewin $\mathrm{SN}$, Herzog $\mathrm{TJ}$, Barrena Medel $\mathrm{NI}$, et al. Comparative performance of the 2009 international Federation of gynecology and obstetrics' staging system for uterine corpus cancer. Obstet Gynecol 2010; 116:1141-9

4. Announcements: FIGO (the International Federation of Obstetricians and Gynecologists) stages: 1988 revision. Gynecol Oncol 1989; 35:1256

5. Meeting Report. The new FIGO staging system for cancers of the vulva, cervix, endometrium and sarcomas. Gynecol Oncol 2009; 115:325-8

6. Bokhman JV. Two pathogenetic types of endometrial carcinoma. Gynecol Oncol 1983; 15:10-7

7. Hamilton CA, Cheung MK, Osann $\mathrm{K}$, et al. Uterine papillary serous and clear cell carcinomas predict for poorer survival compared to grade 3 endometrioid corpus cancers. Br J Cancer 2006; 94:642-6

8. Nonnett BM, Zaino JR, Hendric K. Endometrial carcinoma. In: Kurman RJ, editor. Blaustein's pathology of the female genital tract. 5th ed. New York: Springer-Verlag. 2002; $551-9$

9. Silva EG, Deavers MT, Malpica A. Undifferentiated carcinoma of the endometrium: A review. Pathology 2007; 39: 134-8

10. Altrabulsi B, Malpica A, Deavers MT, Bodurka DC, Broaddus R, Silva EG. Undifferentiated carcinoma of the endometrium. Am J Surg Pathol 2005; 29: 1316-21

11. Ureyen I, Ilgin $H$, Turan $T$, et al. Undifferentiated uterine carcinoma: analysis of eighteen cases. J Obstet Gynaecol 2015; 35: 372-6

12. Ross JC, Eifel PJ, Cox RS, Kempson RL, Hendrickson MR. Primary mucinous adenocarcinoma of the endometrium. A clinicopathologic and histochemical study. Am J Surg Pathol 1983; 7:715-29

13. Felix AS, Weissfeld JL, Stone RA, et al. Factors associated with Type I and Type II endometrial cancer. Cancer Causes Control 2010; 21: 18516

14. Scarfone $G$, Secomandi R, Parazzini $F$, et al. Clear cell and papillary serous endometrial carcinomas: survival in a series of 128 cases. Arch Gynecol Obstet 2013; 287:351-6

15. Ureyen I, Karalok A, Cirik DA et al. A comparison of clinico-pathological characteristics of patients with serous and clear cell carcinoma of the uterus. Turk J Obstet Gynecol 2016; 13: 137-43

16. Lax SF, Kurman RJ, Pizer ES, Wu L, Ronnett BM. A binary architectural grading system for uterine endometrial endometrioid carcinoma has superior reproducibility compared with FIGO grading and identifies subsets of advance-stage tumors with favorable and unfavorable prognosis. Am J Surg Pathol. 2000; 24:1201-8

17. Scholten AN, Smit VT, Beerman $H$, van Putten WL, Creutzberg CL. Prognostic significance and interobserver variability of histologic grading systems for endometrial carcinoma. Cancer 2004; 100:764-72

18. Zaino R. Pathologic indicators of prognosis in endometrial adenocarcinoma: selected aspects emphasizing the GOG experience. Pathol Ann 1995; 30(pt1):1-28

19. Gungorduk K, Ozdemir A, Ertas IE, et al. Is mucinous adenocarcinoma of the endometrium a risk factor for lymph node involvement? A multicenter case-control study. Int J Clin Oncol. 2015; 20:782-9

20. Sakuragi N, Hareyama H, Todo Y. Prognostic significance of serous and clear cell adenocarcinoma in surgically staged endometrial carcinoma. Acta Obstet Gynecol Scand 2000; 79: 311-6.

21. Boruta DM 2nd, Gehrig PA, Groben PA, et al. Uterine serous and grade 3 endometrioid carcinomas: is there a survival difference. Cancer. 2004; 101:2214-21.

22. Nomura H, Aoki $D$, Suzuki N. Analysis of clinicopathologic factors predicting para-aortic lymph node metastasis in endometrial cancer. Int J Gynecol Cancer 2006; 16: 799-804.

23. Kumar S, Podratz KC, Bakkum-Gamez JN. Prospective assessment of the prevalance of pelvic, paraaortic and high paraaortic lymph node metastasis in endometrial cancer. Gynecol Oncol 2014; 132: 38-43. 